LEADING IN THE NHS 
Also by Rosemary Stewart

THE REALITY OF MANAGEMENT

*THE REALITY OF ORGANIZATIONS

*MANAGERS AND THEIR JOBS

*HOW COMPUTERS AFFECT MANAGEMENT

CONTRASTS IN MANAGEMENT

CHOICES FOR THE MANAGER

THE BOSS: The Life and Times of the British Businessman (with Roy Lewis)

THE DISTRICT ADMINISTRATOR IN THE NATIONAL HEALTH SERVICE (with Peter Smith, Jenny Blake and Pauline Wingate)

*Also published by Macmillan 


\section{Leading in the NHS}

A Practical Guide

Rosemary Stewart

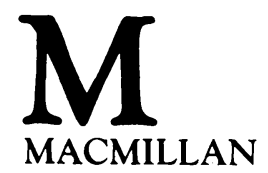


All rights reserved. No reproduction, copy or transmission of this publication may be made without written permission.

No paragraph of this publication may be reproduced, copied or transmitted save with written permission or in accordance with the provisions of the Copyright Act 1956 (as amended), or under the terms of any licence permitting limited copying issued by the Copyright Licensing Agency, 33-4 Alfred Place, London WC1E 7DP

Any person who does any unauthorised act in relation to this publication may be liable to criminal prosecution and civil claims for damages.

First published 1989

Published by

THE MACMILLAN PRESS LTD

Houndmills, Basingstoke, Hampshire RG21 2XS

and London

Companies and representatives

throughout the world

British Library Cataloguing in Publication Data

Leading in the NHS: a practical guide

1. Great Britain. Health services.

Management

I. Title

$362.1^{\prime} 068$

ISBN 978-0-333-48085-4

ISBN 978-1-349-19934-1 (eBook)

DOI 10.1007/978-1-349-19934-1 


\section{Contents}

List of Figures vi

Acknowledgements vii

Guide to Reading This Book ix

Glossary of Acronyms xi

Introduction xii

\section{PART I THE CONCEPT OF LEADERSHIP}

1 Leadership 3

\section{PART II LEADING IN DIFFERENT RELATIONSHIPS}

2 Leading Subordinates

3 Leadership and Nurses 33

4 Leadership and Doctors $\quad 50$

5 Sharing the Leadership 63

6 Leadership and the District Health Authority 72

7 Leadership in the Region-District Relationship 80

8 External Leadership $\quad 90$

\section{PART III LEADERSHIP IN ACTION}

9 Fifteen Young Leaders: Case Studies 1-3 109

10 The Twin Aspects of Leadership: Case Study 4

\section{PART IV DEVELOPING YOURSELF}

11 Managing the Job and Yourself 161

12 Developing Yourself 177

In Conclusion 185

Appendix A: Details of the Templeton Tracer study of DGMs 186 Appendix B: Questions Asked Young Leaders 188 Notes and References 189 Index 195 


\section{List of Figures}

8.1 Network analysis of external relationships: illustrated for a DGM

11.1 Model of a job: demands, constraints and choices

11.2 Who gets most of your attention?

12.1 The 8P diagram 


\section{Acknowledgements}

This book stems from what I have learnt in my discussions and interviews over the years with people in the NHS in a variety of studies including the most recent, the Templeton tracer study of District General Managers (DGMs); I am grateful to them for their interest and help. (The National Health Service Training Authority (NHSTA) funded this tracer study of twenty district managers from the spring of 1985 to the autumn of 1987 , and it was published by them as the Templeton Series on District General Managers.) This book draws upon that study. The views expressed are my own and not necessarily those of the NHSTA.

I am especially grateful to my two research associates on the Templeton project, Sue Dopson and Dr John Gabbay, for their great contribution in all respects to that research and to the nine Issue Studies that came from it (see Appendix A). However, the views expressed in this book may not necessarily be theirs. I am most grateful, too, for their many contributions to the research, to Professor Derek Williams who was consultant to the project and to Peter Smith who was a part-time research associate to the project and with whom I have had the pleasure of working on earlier studies in the NHS.

The DGMs who attend the Templeton DGMs' workshop, which has been meeting since the early days of general management, have helped to keep me up to date with the concerns of DGMs and have provided an opportunity to discuss some of the issues that arose during the tracer study.

It was a pleasure to interview the young leaders described in Chapter 9, and I am encouraged by what I heard. There is clearly some good young talent getting into middle and senior management posts. I owe a particular debt to the DGM who is the subject of Case Study 4 , and who provides such a good example of leadership in action.

I am grateful also to the following who have read and commented helpfully upon part or all of the book at the draft stage: Pat Duff, Sue Dopson, who alone has borne the burden of reading and criticising more than one draft of the book, Dr John Gabbay, Christine Hancock, Dr Deborah Hennessy, Charles Kaye, Dr Bill McQuillan, Mike Marchment, Leslie Paine, John Smyth and Professor Derek 
Williams. Of course the responsibility for the views expressed, and for the remaining defects, are mine. I am grateful to Valerie Martin for her willing and efficient help at all stages. I am also grateful to my Amstrad, and to Word, for making writing a book so much easier, despite the technical hitches.

ROSEMARY STEWART 


\section{Guide to Reading This Book}

Readers from different backgrounds, and at different stages in their career, can use this book, but they should use it differently, hence this guide.

1. If you want to skim the book - Read the Introduction, Contents page, Summary and bold type passages of Chapter 1, the Summaries of the chapters that interest you, and the comments 'In Conclusion' (p. 185).

2. If you only want to read what is most relevant to you - Everyone read the Introduction, Contents page, comments 'In Conclusion' (p. 185) and at least the Summary of Chapter 1.

Who you are

Junior and middle managers in any profession including administration

Senior nurses

Doctors

General managers and other senior managers

\section{What to read}

Chapters 1, 2, 9, 10, 11, 12

Bold type passages and

Summaries of Chapters 3, 4, 8

Chapters 1, 2, 3, 11, 12

Bold type passages and

Summaries of Chapters 4,8

If you like Case Studies, read Chapters 9 and 10 - Case Study 1 is of a hospital manager who is a nurse

Chapters 1, 4 and bold type passages and Summary of

Chapter 3

Chapters 11 and 12 for those involved in management

Chapter 1

Start with the Summary of each chapter, and then read the chapters that interest you 
Chairman, Vice-Chairman Chapters 1, 3, 4, 5, 6

Summary of Chapters 7, 8

You may find the Case Study in

Chapter 10 interesting to compare with your DGM

Members

Chapters 3, 4, 6, 8, 10

Those involved in management Chapters 1, 9-12 and the development in the NHS chapters on relationships that are relevant to those with whom you are working

Students

Chapters 1, 2, 9, 10,11, 12 and any of the others relevant to your course

Others working with the NHS

\section{Chapter 8}

You may also find Chapter 10 of interest

Others

Chapters 1,2,11, 12 are of value to managers in other organisations and to management students 


\section{Glossary of Acronyms}

CHC Community Health Council

CNO Chief Nursing Officer

DA District Administrator

DGM District General Manager

DHA District Health Authority

DMO District Medical Officer

DMT District Management Team

DNA District Nursing Adviser

DNO District Nursing Officer

FPC Family Practitioner Committee

GP General Practitioner

IHSM Institute of Health Services Management

IPR Individual Performance Review

JCC Joint Consultative Committee

MEC Medical Executive Committee

MP Member of Parliament

MSC Manpower Services Commission

NAHA National Association of Health Authorities

NHS National Health Service

NHSTA National Health Service Training Authority

OPCS Office of Population Censuses and Surveys

OT Occupational Therapist

RGM Regional General Manager

RHA Regional Health Authority

RMO Regional Medical Officer

UGM Unit General Manager 


\section{Introduction}

This book has a mission. This mission is to persuade you, the reader, that the NHS needs leadership and that you should be leading, and preparing yourself to be a better leader. There are opportunities for leadership even in junior jobs. My mission is also to help you to understand leadership, to think boldly about what you could achieve and to suggest ways of doing so. It is a guide to leading the different groups that make up the NHS.

My aim is to encourage you to think highly of your role, to lift your head above the immediate pressures and to see yourself as a leader. My message is for present and potential leaders at all levels in the NHS and in all occupations. It is also for Authority members, as you can encourage your managers to be leaders, as well as at times making a leadership contribution yourself.

This book is written because I believe - passionately - that leadership at all levels in the NHS is required to overcome the defeatist tendencies that have been a characteristic of the NHS over the years. ${ }^{1}$

In 1984-5 the introduction of general management into the NHS led to a major reorganisation. The 1989 NHS review means more radical change. Leadership is now both more necessary, and more possible, than in the past. Management and administration remain necessary and it is important that they are well done. What is new is the growing need for leadership to help staff, whatever their professional background, to tackle the new situations with which they are faced.

Most books for NHS readers are about functions like planning, about resource allocation or structures. Surprisingly few are about the people in the NHS. ${ }^{2}$ Yet the work of organisations gets done mainly through people, particularly in a service like the NHS. Changes affect people and to be implemented successfully require their support. Enthusiastic commitment and well directed energy are the marks of well led organisations that cope successfully with changes whatever their cause. Leadership can generate this commitment: leaders to do this are needed at all levels in the NHS.

The book originates from a two and a half year study, from 1985-7, of a sample of 20 District General Managers (DGMs) in the NHS in England and Wales, ${ }^{3}$ from an earlier study of District Administrators 
(DAs) ${ }^{4}$ from a current study of changes affecting middle managers in all kinds of organisations, and from the author's experience of teaching managers in industry, commerce and the public service (including the NHS), how to review their effectiveness. The author has also co-directed an international conference on leadership. ${ }^{5}$

Part I, Chapter 1 describes the concept of leadership, and how it differs from management and administration, though all three are needed in the NHS. Part II is about how to lead the different kinds of individuals and groups with whom leaders in the NHS may have to work. Its introduction describes five common reasons for friction, and gives some general guidance on managing relationships and managing change. Each of the chapters in Part II has a common format:

1. A statement of the ideal to aim at.

2. Difficulties likely to be encountered in achieving the ideal.

3. Steps to be taken towards achieving the ideal.

These steps are based on the experience of leaders in the NHS and in other organisations. You can use the statement of the ideal as a checklist of points when deciding on your own. You can use the account of the difficulties as a warning of those problems you may need to overcome. The statement of steps to be taken will help you to decide how to achieve your ideal.

Part III gives practical examples of leadership in the NHS. Chapter 9 is based on interviews with fifteen young leaders in different occupations within the NHS and at different levels. Twelve of these are discussed together with individual illustrations, and three are longer accounts of how the individual describes and then goes about leading. These are Case Studies 1-3, which have questions at the end so that you can consider their relevance for you. Chapter 10 is a more detailed Case Study of a DGM which describes both his own views on, and his practice of, leadership and how his main contacts described and assessed his approach. The accounts of young leaders are there to encourage young readers to follow their example, and older managers to remember the importance of identifying and developing potential leaders. The Case Studies are there as examples of how different leaders tackle their jobs.

Part IV is intended to help you to become a more effective leader. Chapter 11 is about managing yourself and your job, and provides a variety of suggestions and models for doing so. It is therefore about management as well as leadership. It emphasises the need to improve 
your understanding - of yourself, of your job and of ways of becoming more effective in your job. Chapter 12 is about how to develop yourself. The final comments, In Conclusion, are intended to encourage you to act on what you have read.

Knowing how busy you are, the book is designed to be read in two ways: to be skimmed for its main messages or to be read for its detailed help in deciding what you want to achieve, what difficulties you will have to overcome, and how to go about it. The Guide to Reading This Book on pp. ix- $x$ will help you to identify the sections that are most relevant to you, depending on your position.

References are mainly given to acknowledge a quotation, or when the reader may be looking for help. The book is addressed to you, not to fellow academics, though they may find some sections useful for teaching in managerial programmes.

The book follows others in avoiding exclusive use of 'he' for men and women by the use of both 'she' and 'he', by the use of the plural, and sometimes of 'he and she'. I have used the term 'Chairman' because that is still the official description for men and women who are appointed to chair their Authorities.

Templeton College, Oxford

Rosemary STEWART

February 1989 